\title{
Kedudukan Hukum Perseroan Terbatas Yang Belum Berstatus Badan Hukum*
}

\author{
Oleh: \\ Ni Made Lalita Sri Devi** \\ I Made Dedy Priyanto*** \\ Program Kekhususan Hukum Bisnis Fakultas Hukum \\ Universitas Udayana
}

\begin{abstract}
ABSTRAK
Penulisan jurnal ini berlatar belakang terhadap Perseroan Terbatas atau yang disebut PT yang belum berstatus badan hukum. Dari latar belakang tersebut diangkat masalah yaitu, akibat hukum terhadap Perseroan Terbatas yang belum berstatus badan hukum yang pailit dan tanggung jawab Direksi Perseroan Terbatas yang pailit dan belum berstatus badan hukum. Penulisan ini bertujuan untuk mengetahui lebih dalam terhadap akibat Perseroan Terbatas yang belum berstatus badan hukum yang pailit dan mengetahui tanggung jawab Direksi Perseroan Terbatas yang pailit dan belum berstatus badan hukum. Penulisan ini menggunakan hukum normatif dengan menggunakan sumber bahan hukum primer berupa

* Makalah Ilmiah Ini Merupakan Ringkasan Diluar Skripsi

**Ni Made Lalita Sri Devi adalah mahasiswa Fakultas Hukum Universitas Udayana,

***I Made Dedy Priayanto adalah dosen pengajar Fakultas Hukum Universitas Udayana, dedy.priyato23@yahoo.com
\end{abstract} lalitands@yahoo.co.id 
asas-asas hukum, kaidah-kaidah hukum dan bahan hukum sekunder berupa buku-buku hukum, dan jurnal-jurnal hukum. Kesimpulan dalam penulisan ini akibat hukum terhadap Perseroan Terbatas yang belum berstatus badan hukum yang pailit yaitu beralihnya kewenangan pada Direksi kepada kurator untuk mengelola perseroan dan tanggung jawab Direksi juga menjadi tanggung jawab pribadi, tidak mengikat pada Perseroan.

Kata kunci : Tanggung jawab, Perseroan Terbatas, Direksi, Pailit.

\section{ABSTRACT}

The writing of this journal has a background to a Limited Company or is called a PT that is not yet a legal entity. Therefore, the issues raised from above topic will be the consequences of a Limited Liability Company who has not been registered as a legal entity happen bankruptcy and responsibility of the Board of Directors for bankruptcy Limited Liability Companies that are not yet incorporated. This journal aims to find out more about the consequences of a Limited Liability Company that has not become a bankrupt legal entity and knows the responsibility of the Board of Directors for bankruptcy Limited Liability Companies that are not yet incorporated..The method used in this journal are normative law by using sources of primary legal material in the form of legal principles, legal rules and secondary legal material in text books, and legal journals. It can be concluded that the consequences of a Limited Liability Company who has not been registered as a legal entity happen bankruptcy is the transfer of authority to the 
Board of Directors becomes to the curator to manage the company and the responsibility of the Board of Directors is also a personal responsibility, not binding on the Company.

\section{Keywords: Responsibilities, Limited Liability Company, Directors, Bankruptcy.}

\section{PENDAHULUAN}

\section{$1.1 \quad$ Latar Belakang}

Perkembangan perekonomian di era globalisasi ini untuk masa sekarang dan untuk dimasa yang akan datang, demi memperoleh kesejahtraan masyarakat banyak pengusaha yang memiliki usaha tumbuh dengan pesat. Pembangunan ekonomi merupakan bagian dari pembangunan nasional yang bertujuan untuk mewujudkan kesejahteraan rakyat yang berlandaskan pada Undang-Undang Dasar Negara Republik Indonesia Tahun 1945 (UUD 1945). Hal ini telah ditegaskan pada pasal 33 ayat (4) UUD 1945 yang menentukan bahwa : Perekonomian Nasional yang diselenggarakan berdasarkan demokrasi ekonomi dengan prinsip kebersamaan, efisiensi, berkeadilan, berkelanjutan, berwawasan lingkungan, kemandirian serta dengan menjaga keseimbangan dalam kegiatan usaha besar, menengah dan kecil dalam pola kemitraan.

Perseroan Terbatas merupakan salah satu perusahaan yang diharapkan dapat menjadi sarana dalam meningkatkan pembangunan ekonomi. Dipilihnya Perseroan Terbatas sebagai bentuk 
perusahaan dikarenakan pertama, Perseroan Terbatas merupakan asosiasi modal dimana sebagai asosiasi modal maka akan mempermudah pemegang saham Perseroan Terbatas untuk menyerahkan sahamnya kepada orang lain dan kedua, Perseroan Terbatas adalah badan hukum yang mandiri menurut Undang-Undang Perseroan Terbatas maka tanggung jawab pemegang saham bersifat terbatas.

Perseroan Terbatas memiliki pengertian suatu perusahaan berbentuk dalam badan hukum yang didirikan oleh dua orang atau lebih atas perjanjian oleh para pendirinya demi melakukan kegiatan usaha dengan modal dasar yang seluruhnya tercantum dalam saham dan memenuhi persyaratan didalam peraturan dalam Undang-Undang Perseroan Terbatas. ${ }^{1}$ Dalam pembentukan perusahaan telah diatur Undang-Undang Nomor 40 Tahun 2007 tentang Perseroan terbatas atau yang disingkat sebagai UU PT.

Perseroan Terbatas memiliki karakteristik yaitu adanya kekayaan yang terpisah, mempunyai tujuan tertentu, mempunyai kepentingan sendiri dan adanya organisasi teratur. Untuk itu Perseroan Terbatas harus diperhatikan bagaimana usaha yang dilakukan dan bagaimana tanggung jawab yang ada di badan usaha tersebut, perbuatan hukum yang telah dilakukan oleh para pendiri Perseroan Terbatas sebelum Perseroan Terbatas menjadi badan hukum akan bisa menjadi masalah yang berkepanjangan,

1 Munir Fuady, 2003, Perseroan Terbatas Paradigma Baru, PT citra Aditya Bakti, Bandung, h.1. 
tindakan ini memeberikan dampak hukum yang besar.

Badan hukum merupakan lapangan hukum harta kekayaan maka badan hukum sama seperti individu perorangan yaitu dengan dapat digugat atau akan menggugat demi perikatannya. ${ }^{2}$ Karena itu pentingnya mengetahui aturan, wewenang dan fungsinya yang diatur sesuai Undang-Undang Perseroan Terbatas, untuk Perseroan Terbatas yang belum berbadan hukum juga harus memperhatikan kepastian yang ada artinya sesudah Perseroan Terbatas resmi menjadi badan hukum jadi perbuatan hukum itu akan wajib dinyatakan diterima dan dikukuhkan bagi Perseroan. ${ }^{3}$

Seringnya terjadinya masalah yang ada dalam pendirian Perseroan Terbatas dan aktivitas Perseroan Terbatas yang belum berbadan hukum berdasarkan urairan diatas sangat menarik untuk dilakukan penelitian yang berupa penulisan jurnal karya ilmiah yang berjudul "Kedudukan Hukum Perseroan Terbatas Yang Belum Berstatus Badan Hukum”

\subsection{Rumusan Masalah}

1. Bagaimanakah akibat hukum terhadap Perseroan Terbatas yang belum berstatus badan hukum yang pailit ?

2. Bagaimanakah tanggung jawab Direksi Perseroan Terbatas yang pailit dan belum berstatus badan hukum?

\footnotetext{
h.107.

2 Muhamad Sadi, 2014, Hukum Perusahaann Di Indonesia, Kencana, Jakarta,

3 Try Widiyono, 2008, Direksi Perseroan Terbatas, Ghalia Indonesia, Bogor, h.109.
} 


\subsection{Tujuan Penulisan}

Penulisan ini dibuat dengan memiliki tujuan untuk mengetahui akibat hukum terhadap Perseroan Terbatas yang belum berbadan hukum yang pailit dan untuk mengetahui tanggung jawab Direksi Perseroan Terbatas yang pailit dan belum berstatus badan hukum.

\section{ISI MAKALAH}

\subsection{Metode Penulisan}

Untuk menyelesaikan permasalahan penulisan ini adalah menggunakan metode hukum normatif 4 dengan menggunakan sumber bahan hukum primer berupa asas-asas hukum, kaidah-kaidah hukum dan bahan hukum sekunder berupa buku-buku hukum, dan jurnal-jurnal hukum.

\subsection{Hasil dan Analisis}

\subsubsection{Akibat Hukum Terhadap Perseroan Terbatas}

\section{Yang Belum Berbadan Hukum Yang Pailit}

Kegiatan yang diperlukan mulai pengajuan sampai Perseroan Terbatas telah dinyatakan sebagai badan hukum dengan memperoleh pengesahan oleh Keputusan Menteri Hukum dan Hak Asasi Manusia. Selama menunggu, maka pendiri akan melalukan perbuatan hukum yang akan diperlukan yaitu :

a. Para anggota pendiri harus beruapaya menyelesaikan hal-hal yang diperlukan seperti misalnya dalam transaksi.

4 Amirudin dan Zainal Asikin, 2003, Pengantar Metode Penelitian Hukum, PT Raja Grafindo Persada, Jakarta, h.119. 
b. Anggota Direksi yang telah diangkat dan namanya yang telah dicantumkan didalam akta pendirian Perseroan Terbatas boleh memulai melakukan kegiatan dengan pihak ketiga.

Apabila RUPS tidak dilaksanakan dengan jangka waktu 60 hari setalah Perseroan Terbatas memiliki status sebagai badan hukum atau RUPS tidak berhasil mengambil keputusan dengan demikian pendiri yang telah melakukan perbuatan hukum itu akan bertanggung jawab sebagai pribadi akibat yang timbul. RUPS tidak diperlukan apabila telah disetujui dengan secara tertulis untuk semua pendiri sebelum melakukan pendirian Perseroan Terbatas. 5

Pengambilan hak dan kewajiban dari perbuatan hukum yang telah dilakukan pendiri demi kepentingan Perseroan Terbatas yang belum berstatus sebagai badan hukum, tidak boleh menyimpang dalam anggaran dasar, diluar yang ditetapkan terhadap pasal 13 ayat (1) UndangUndang Perseroan Terbatas.

Undang-Undang Nomor 37 Tahun 2004 tentang Kepailitan dan Penundaan Kewajiban Pembayaran Utang definisi mengenai kepailitan dalam Pasal 1 ayat (1) yaitu Kapailitan adalah Sita umum atas semua kekayaan debitor pailit yang pengurusan dan pemberesannya dilakukan oleh kurator di bawah pengawasan hakim pengawas sebagaimana diatur dalam undang-undang ini.

${ }^{5}$ Azizah, 2016, Hukum Perseroan Terbatas, Setara Press, Malang, h.39. 
Kepailitan terhadap Perseroan Terbatas yang menjadi permasalahan yang esensial adalah Perseroan Terbatas tersebut tetap dapat beroperasi atau demi hukum harus bubarkan. Dalam kepailitan Perseroan Terbatas, beroperasi atau tidaknya perseroan setelah putusan pailit dibacakan tergantung pada cara pandang kurator terhadap prospek usaha perseroan pada waktu yang akan datang. Hal ini karenakan berdasarkan ketentuan di dalam Pasal 104 Undang-undang Kepailitan dan Penundaan Kewajiban Pembayaran Utang yang menyatakan :

1. Berdasarkan persetujuan panitia kreditor sementara, kurator dapat melanjutkan usaha debitur yang dinyatakan pailit walaupun terhadap pernyataan putusan pailit tersebut diajukan kasasi atau peninjauan kembali.

2. Apabila dalam kepailitan tidak diangkat panitia kreditur, kurator memerlukan izin hakim pengawas untuk melanjutkan usaha sebagaimana dimaksud dalam ayat (1).

Berdasarkan ketentuan pasal di atas disimpulkan bahwa kepailitan Perseroan Terbatas di Indonesia tidak secara otomatis membuat Perseroan kehilangan haknya untuk mengurus dan menguasai harta kekayaan Perseroan tersebut, karena kepailitan Perseroan terbatas menurut hukum Indonesia tidak menyebabkan berhentinya dalam operasional Perseroan. Tetapi dalam hal Perseroan yang dilanjutkan ternyata tidak berprospek dengan baik, maka hakim pengawas akan memutuskan untuk menghentikan 
beroperasinya Perseroan Terbatas dalam permohonan seorang kreditur. Setelah Perseroan tersebut dihentikan, maka kurator mulai menjual aktiva boedel tanpa memerlukan bantuan atau persetujuan debitur pailit. Dalam prakteknya kepailitan Perseroan Terbatas adalah juga kepailiatan bagi Direksinya karena implikasi dari adanya kepailitan itu tetap mengikuti Direksi.

\subsubsection{Tanggung Jawab Direksi Perseroan Terbatas} Yang Pilit Dan Belum Berstatus Badan Hukum

Perseroan Terbatas merupakan subjek hukum yang menimbulkan hak dan kewajiban dalam perseroan. 6 Bagi Perseroan Terbatas yang belum berbadan hukum bawah Perseroan Terbatas tersebut tidak terpisah kekayaannya dengan pengurusnya. ${ }^{7}$ Dalam perbuatan subjek hukum Perseroan Terbatas ini pelaksanaannya dapat dijalankan dengan Direksi yang bertindak sebagai pengurus pelaksanaan Perseroan Terbatas disini Direksi juga merupakan subjek hukum dan dapat melakukan perbuatan hukum oleh pihak ketiga.

Direksi adalah organ Perseroan yang berwenang dan bertanggung jawab penuh atas pengurusan Perseroan untuk kepentingan Perseroan sesuai dengan maksud dan tujuan Perseroan serta mewakili perseroan, baik didalam maupun diluar pengadilan sesuai dengan ketentuan anggaran dasar. Dalam perbuatan hukum

6 Tri Widiyono, 2008, Direksi Perseroan Terbatas, Ghalia Indonesia, Jakarta, h.10.

7 Gatot Supramono, 2007, Kedudukan Perusahaan Sebagai Subjek Dalam Gugatan Perdata Di Pengadilan, PT Rineka Cipta, Jakarta, h.136. 
dilakukan dengan Direksi sebelum Perseroan Terbatas berbadan hukum telah diatur dalam Pasal 14 Undang-Undang Perseroan Terbatas perbuatan hukum yang atas nama Perseroan yang belum memperolah status sebagai badan hukum itu hanya boleh dilakukan seluruh anggota Direksi bersamasama pendiri \& seluruh anggota Dewan Komisaris Perseroan dan itu merupakan tanggung jawab yang secara tanggung renteng karena perbuatan hukum.

Perbuatan hukum yang telah dilakukan dengan pendiri sebelum Perseroan Terbatas berbadan hukum walaupun perbuatan hukumnya sudah dilakukan demi kepentingan perseroannya sebagaimana telah disebutkan Pasal 92 ayat (1) dan (2) Undang-undang Perseroan Terbatas, pertama Direksi menjalankan pengurusan Perseroan untuk kepentingan Perseroan dan sesuai dengan maksud dan tujuan tertentu. Kedua Direksi berwewenang menjalankan pengurusan sebagaimana dimaksud pada ayat (1) sesuai dengan kebijakan yang dipandang tepat, dalam batas yang ditentukan undang-undang ini dan atau anggaran dasar.

Perbuatan hukum oleh Direksi selaku subjek hukum dari Perseroan Terbatas yang belum berbadan hukum pada Pasal 14 ayat (2) Undangundang Perseroan Terbatas resmi menjadi tanggung jawab pendiri secara tanggung renteng, meskinpun perbuatan hukum yang telah dilakukan para pendiri, Direksi \& Dewan Komisaris sebelum Perseroan Terbatas berstatus sebagai badan hukum. Pasal 14 ayat (1) Undang-Undang Perseroan Terbatas menyebutkan itu jadi tanggung jawab 
renteng kemudian jika dalam pelaksanaan perbuatan hukum yang dilakukan Direksi mengakibatkan kerugian Perseroan Terbatas ataupun telah merugikan pihak ketiga sebelum Perseroan Terbatas berstatus badan hukum bertanggung jawab atas kerugian itu menjadi sepenuhnya tanggung jawab Direksi sama sekali tidak dibebankan pada Perseroan Terbatas merupakan tidak menjadi tanggung jawab Perseroan, tetapi akan menjadi tanggung jawab secara tanggung renteng.

Demi memenuhi kerugian dari perbuatan hukum itu Direksi dengan pihak yang telah dirugikan dapat menggugat pada pelaku perbuatan hukum itu dengan cara pribadi dan tidak pada Perseroan Terbatas dengan demikian perbuatan Direksi itu dilakukan demi nama Perseroan Terbatas. Berdasarkan penjelasan itu sudah jelas bahwa tanggung jawab terjadinya kerugian pada perbuatan hukum itu ada pada para Direksi. Sifat tanggung jawab pribadi Direksi menjadi sangat relevan dalam hal direksi melakukan penyimpangan atas kuasa dan perintah perseroan untuk kepentingan Perseroan. ${ }^{8}$

Dengan perjanjian tanggung jawab perbuatan hukum Direksi yang menjalankan dalam kegiatan usaha Perseroan Terbatas yang belum berstatus badan hukum tetap sah dan tetap berlaku sebagai Undang-Undang untuk para pembuatnya, maka

${ }^{8}$ Siti Hapsah Isfardiana, 2015, Tanggung Jawab Direksi Perseroan Terbatas dalam Pelanggaran Fiduciary Duty, Universitas Padjadjaran, Volume 02, Nomor 01, Bandung, h.17. 
dari itu dalam pelaksanaan perbuatan hukum Direksi tidak memperoleh persetujuan dari RUPS pertama setelah Perseroan Terbatas berstatus badan hukum jadi tanggung jawab itu menjadi tanggung jawab pribadi dari Direksi dengan cara tanggung renteng dan tidak akan terbatas dari modal yang telah disetorkan pada Perseroan Terbatas, tetapi tanggung jawab hingga dengan harta pribadi dan atas kerugian Perseroan Terbatas itu hanya bisa diajukan pada Direksi bukan pada Perseroan Terbatas sebab perbuatan hukum para pendiri, Direksi melalukan sebelum Perseroan Terbatas berstatus sebagai badan hukum.

Dalam hal ini akan menjadi pertentangan tersendiri sebab dalam praktek sebenarnya Direksi yang lebih mengetahui tentang seluk beluk dari Perseroan Terbatas, pasar serta konsumen dari Perseroan jika pailit. ${ }^{9}$

\section{PENUTUP}

\subsection{Kesimpulan}

1. Akibat hukum terhadap Perseroan Terbatas yang belum berstatus badan hukum yang pailit yaitu beralihnya kewenangan Direksi kepada kurator untuk mengelola perseroan dan kurator bertindak sebagai Direksi maka dari itu tanggung jawab Direksi Perseroan Terbatas juga menjadi tanggung jawab kurator.

9 Nadya Karunia Normayunita, 2018, Tanggung Jawab Direksi Atas Kepailitan Perseroan Terbatas Menurut Undang-Undang Nomor 40 Tahun 2007, Universitas Udayana, Volume 06, Nomor 05, Bali, h.14. 
2. Tanggung jawab Direksi Perseroan Terbatas yang pailit dan belum berstatus badan hukum dalam perbuatan hukumnya mengalami kerugian maka Direksi bertanggung jawab secara pribadi dan tidak mengikat pada Perseroan Terbatas.

\subsection{Saran}

1. Hendaknya Perseroan Terbatas tersebut menaati Peraturan Perundang-undangan yang berlaku dan harus berstatus badan hukum sehingga akan memperjelas kedudukan dan tanggung jawabnya.

2. Terhadap Perseroan Terbatas yang belum berstatus badan hukum hendaknya Direksi tidak melakukan aktivitas seperti transaksi financial karena jika terjadinya perbuatan hukum akan mengakibatkan resiko yang merugikan Direksi itu sendiri dan tidak mengikat pada Perseroan. 


\section{DAFTAR PUSTAKA}

\section{Buku-buku :}

Amirudin dan Zainal Asikin, 2003, Pengantar Metode Penelitian Hukum, PT Raja Grafindo Persada, Jakarta.

Azizah, 2016, Hukum Perseroan Terbatas, Setara Press, Malang.

Gatot Supramono, 2007, Kedudukan Perusahaan Sebagai Subjek Dalam Gugatan Perdata Di Pengadilan, PT Rineka Cipta, Jakarta.

Tri Widiyono, 2008, Direksi Perseroan Terbatas, Ghalia Indonesia, Jakarta.

Munir Fuady, 2003, Perseroan Terbatas Paradigma Baru, PT citra Aditya Bakti, Bandung.

Muhamad Sadi, 2014, Hukum Perusahaann Di Indonesia, Kencana, Jakarta.

Jurnal Ilmiah :

Nadya Karunia Normayunita, 2018, Tanggung Jawab Direksi Atas Kepailitan Perseroan Terbatas Menurut Undang-Undang Nomor 40 Tahun 2007, Universitas Udayana, Volume 06, Nomor 05, Bali.

Siti Hapsah Isfardiana, 2015, Tanggung Jawab Direksi Perseroan Terbatas dalam Pelanggaran Fiduciary Duty, Universitas Padjadjaran, Volume 02, Nomor 01, Bandung.

\section{Peraturan Perundang-undangan :}

Undang-Undang Dasar Negara Republik Indonesia Tahun 1945. 
Undang-Undang Republik Indonesia No 40 Tahun 2007 Tentang Perseroan Terbatas.

Undang-Undang Nomor 37 Tahun 2004 Tentang Kepailitan dan Penundaan Kewajiban Pembayaran Utang. 